\title{
Comparison of the trace metal concentration of drinking water supply options in southwest coastal areas of Bangladesh
}

\author{
Md. Atikul Islam • Md. Rezaul Karim • \\ Takaya Higuchi · Hiroyuki Sakakibara \\ Masahiko Sekine
}

Received: 24 March 2013/Accepted: 29 October 2013/Published online: 21 November 2013

(C) The Author(s) 2013. This article is published with open access at Springerlink.com

\begin{abstract}
In the coastal areas of Bangladesh, scarcity of drinking water is acute as the fresh water aquifers at reasonable depths are not available and surface water is highly saline. Households are mainly dependent on rainwater harvesting, pond sand filter (PSF), and rain-fed pond water for drinking purposes. To ascertain the water quality for human consumption, chemical parameters such as $\mathrm{pH}$, conductivity and the concentrations of calcium, magnesium, iron, manganese, copper, zinc, lead, chromium, cadmium, nickel and arsenic were evaluated in the alternative drinking water supply options employed in the southwest coastal areas of Bangladesh. An inductively coupled plasma-optical emission spectroscopy was used for determination of trace metal concentrations. $\mathrm{pH}$ and
\end{abstract}

M. A. Islam ( $\square)$

Environmental Science Discipline, Khulna University,

Khulna 9208, Bangladesh

e-mail: atikku_es@yahoo.com

\section{R. Karim}

Department of Civil and Environmental Engineering,

Islamic University of Technology, Gazipur,

Dhaka 1704, Bangladesh

e-mail: rezaulmd@gmail.com

\section{T. Higuchi $\cdot$ H. Sakakibara $\cdot$ M. Sekine}

Graduate School of Science and Engineering,

Yamaguchi University, 2-16-1 Tokiwadai, Ube,

Yamaguchi 755-8611, Japan

e-mail: takaya@yamaguchi-u.ac.jp

H. Sakakibara

e-mail: sakaki@yamaguchi-u.ac.jp

M. Sekine

e-mail: ms@yamaguchi-u.ac.jp conductivity were measured using HANNA Instrument. The mean iron and manganese concentrations for rain-fed pond and PSF water were much higher than harvested rainwater. The iron concentrations for $41 \%$ of the pond water samples were higher than the Bangladesh guideline value. Iron and manganese removal by PSFs was found to be 74 and $51 \%$, respectively. Scarcity of calcium and magnesium were found in harvested rainwater. Furthermore, one pond water sample showed arsenic concentration above the $10 \mu \mathrm{g} / \mathrm{l}$ WHO drinking water guideline. The presence of an elevated iron and manganese and low calcium and magnesium concentrations in the drinking water could be a matter of public health concern.

Keywords Bangladesh - Coastal areas - Drinking water . Trace metal concentrations

\section{Introduction}

In Bangladesh, $73 \%$ of the population lives in rural areas, and tubewell water is the primary source of drinking water for the majority of the rural population. However, in the coastal areas, drinking water is very scarce since suitable fresh water aquifers at reasonable depths are not available and the surface water is highly saline and turbid. There are certain areas in the coastal districts where both shallow and deep tubewells are not useful due to high salinity in groundwater. In many places in these areas, rainwater is preserved in natural reservoir ponds and collection of rainwater is the only source of drinking water (Kamruzzaman and Ahmed 2006). Moreover, the presence of excessive arsenic in shallow tubewell water has been reported in 59 out of 64 districts in Bangladesh, and it is estimated that 35-77 million people are at the risk of

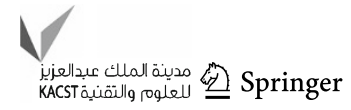



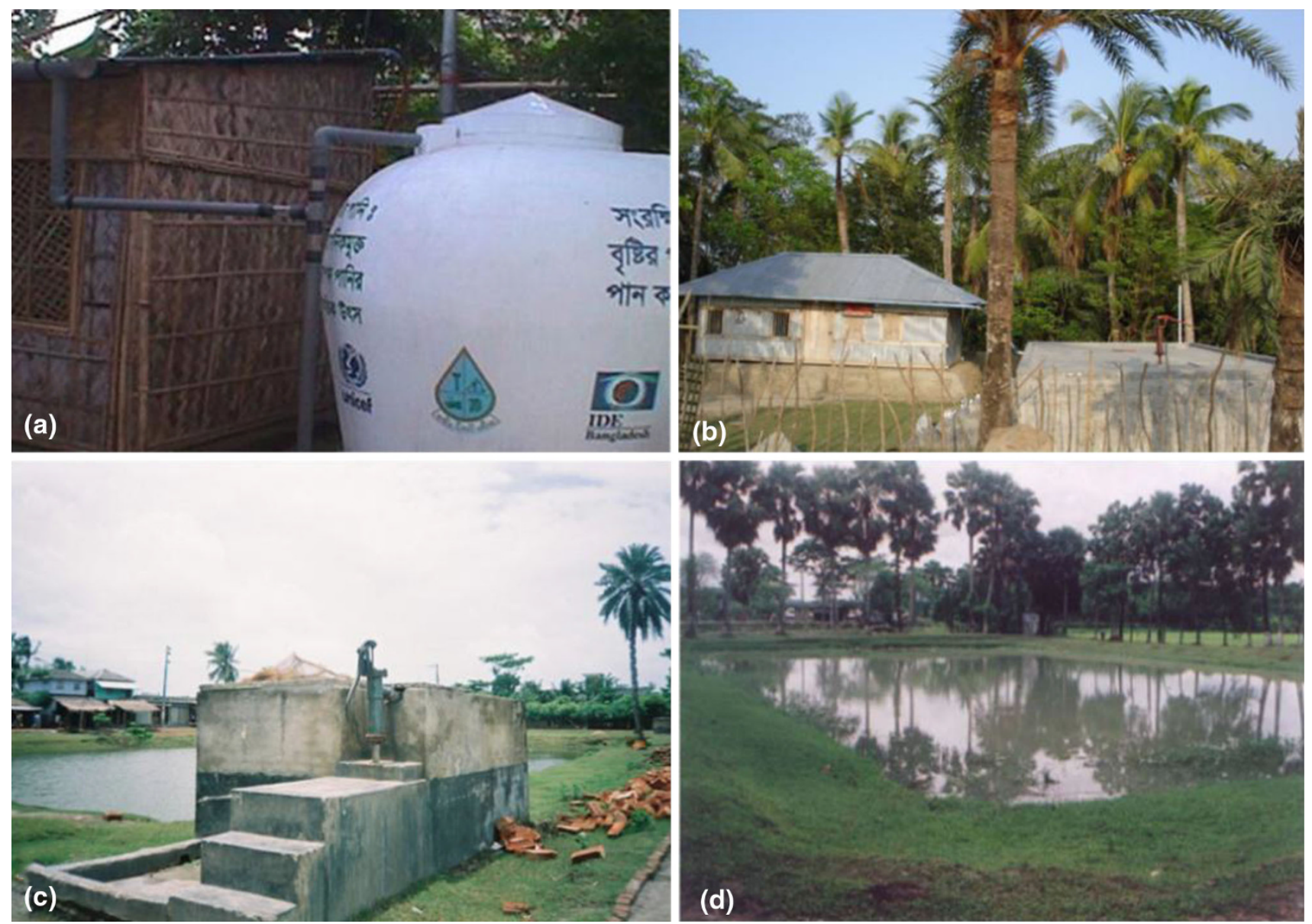

Fig. 1 Drinking water options: a household-based rainwater harvesting system; b community-based rainwater harvesting system; $\mathbf{c}$ PSF; $\mathbf{d}$ pond

drinking arsenic-contaminated tubewell water (GOB 2000). Accordingly, it is necessary to supply safe water to protect the health and well being of the rural population living in the coastal and arsenic-affected areas of Bangladesh. In the coastal and arsenic-affected areas of Bangladesh, the government is promoting alternative water supply options such as rainwater harvesting, and pond-sand filters (PSFs). The currently used water supply options in rural southwest coastal areas of Bangladesh are: householdbased rainwater harvesting systems (RWHSs), communitybased rainwater harvesting systems (CRWHSs), PSFs, and rain-fed pond water (Fig. 1). PSF, a special small scale filtering device has been used mainly in the coastal parts of Bangladesh to treat the water from rain-fed ponds. It is a manually operated treatment unit, based on the principal of slow sand filtration. Water is pumped up from the pond by a handpump and is poured into a small concrete tank, having more compartments, of which one is the filter chamber filled with the sand. Water passes through the sand filter chamber from where it flows into adjacent storage chamber. A small chamber filled with brick chips acts as a pre-treatment unit. Schematic diagram of PSF is

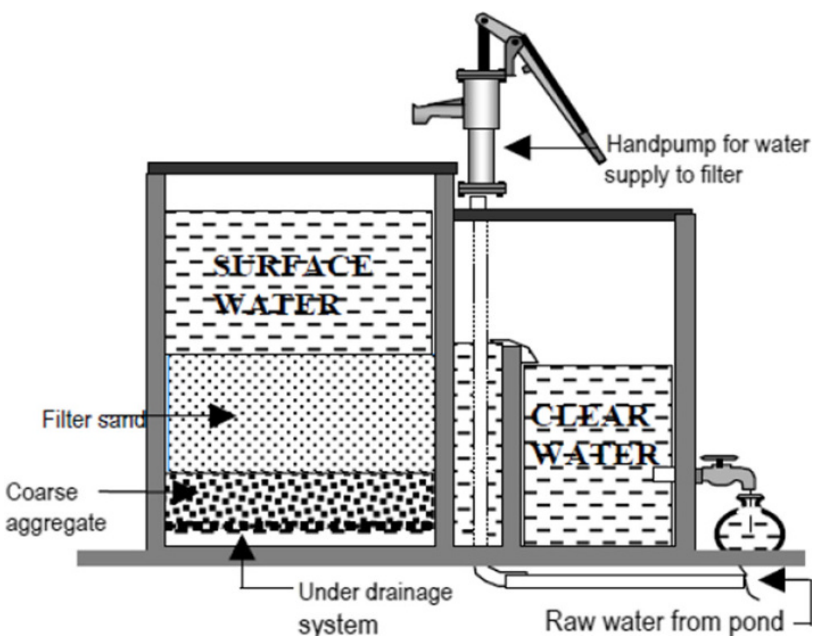

Fig. 2 Schematic diagram of PSF

shown in Fig. 2. The treated water quality depends on the efficiency of filtration system and also on the raw water quality of the pond. Again, the water quality of the pond depends on design of the pond, the use being made of the 
pond by people and or livestock, and the runoff into the pond of drainage and wastewater.

It is well known that dissolved metals are more readily absorbed from drinking water than from most foodstuffs and, therefore, metal toxicity may be higher through drinking water intake. Bio-available metals present in drinking water may cause several diseases to humans. A number of studies have indicated that metal concentrations in harvested rainwater tanks exceed recommended level suitable for human consumption (Simmons et al. 2001; Magyar et al. 2008). Rainwater harvesting system components, e.g. fittings and downpipes appear to be affected soft water corrosion, resulting in high concentrations of some metals (copper, zinc, and aluminium) (Ward et al. 2010). In the rural areas of Bangladesh, corrugated galvanized iron sheet roofs are commonly used for collection of rainwater. Use of metal roofs for collection of rainwater has been shown to be a source of zinc (Simmons et al. 2001; Gromaire et al. 2002; Handia 2005). Elevated zinc intakes can cause demyelinating diseases in humans (Zatta et al. 2003). Lead was observed in harvested rainwater collected from galvanized iron roof (Simmons et al. 2001). Rain water has the possible chemical scarcity of some bio-essential elements such as calcium and magnesium (Uba and Aghogho 2000). The scarcity of calcium and magnesium in drinking water has been associated with cardiovascular diseases (Yang et al. 2006). The risk of drinking pond water is greatly concerned since farmers use chemical fertilizers and insecticides in the paddy fields which are washed away by rain water into the pond and contaminates it. In addition, arsenic has been detected from pond and PSF water in Bangladesh (Yokota et al. 2001; Howard et al. 2006).

Previous studies of alternative water supply options in Bangladesh have primarily focused on microbiological quality (Howard et al. 2006; Karim 2010a). There is little information on trace metal concentrations in these alternative drinking water options. Thus, the objective of the study was to evaluate some chemical parameters such as $\mathrm{pH}$ and conductivity and the concentrations of calcium, magnesium, iron, manganese, copper, zinc, lead, chromium, cadmium, nickel and arsenic in alternative drinking water options employed in the southwest coastal areas of Bangladesh, as a way to ascertain the water quality for human consumption.

\section{Methodology}

Water samples were collected from the Dacope and Mongla Upazilas (sub-district) of the Khulna and Bagerhat districts located in the southwest coastal areas of Bangladesh. Samples were collected from RWHSs, CRWHSs, PSFs, and rain-fed ponds. We considered PSF relevant rain-fed ponds as PSF ponds. Water samples from both
Table 1 Sampling sources and number of samples taken from each option

\begin{tabular}{lll}
\cline { 2 - 2 } & RWHSs & 20 \\
& CRWHSs & 14 \\
& PSFs & 17 \\
Ponds & 39 \\
Out of 39 ponds 17 were PSF & Total & 90 \\
\hline
\end{tabular}

PSFs and PSF ponds were collected to examine the metal concentration after sand filtration. For RWHSs, plastic and ferrocement tanks were considered in the present study, since the government and NGOs have been promoting plastic and ferrocement tanks for rainwater harvesting. CRWHSs tanks are made of reinforced cement concrete (RCC) or ferrocement. A total of 90 water samples were collected (Table 1) during March 2009.

Water from different water supply options was collected following the standard procedures (APHA 1998) using polyethylene bottles. For trace metal analysis, samples were acidified with concentrated nitric acid to a $\mathrm{pH}$ of 2 . This was done to prevent the precipitation of metals. The temperature of all stored samples was maintained at $0-4{ }^{\circ} \mathrm{C}$ until immediately before analysis. Samples were allowed to warm up to room temperature before analysis.

The $\mathrm{pH}$ and conductivity of the samples were measured on site. An inductively coupled plasma-optical emission spectroscopy (ICP-OES) (Perkin Elmer Optima 3300DV) was used for determination of trace metal concentrations. The samples were digested using concentrated nitric acid. Concentrated nitric acid $(5 \mathrm{ml})$ was added to the samples and heated on a hot plate to boil until its volume reduced to $10 \mathrm{ml}$. Additional nitric acid was added until the solution becomes transparent. The solution was allowed to cool and quantitatively transferred into a $20 \mathrm{ml}$ volumetric flask and made up to the mark with distilled water. Blank solutions were handled in exactly the same way as the samples. The concentrated samples were filtered through $0.45 \mu \mathrm{m}$ membrane filters. Standard stock solutions $(1,000 \mu \mathrm{g} / \mathrm{l})$ were used to prepare a multi-element calibration standard solution and all results blank-corrected. Instrument start-up and optimization were carried out as detailed in the operating manual. Average values of three replicates were taken for each determination. Arsenic concentrations were determined using atomic absorption/flame emission spectrophotometer (Shimadzu AA-660GPC). Calibration curve was drawn by running suitable concentrations of standard solutions, from which the concentrations of the elements were obtained by extrapolation. In addition, samples blanks were analyzed after 7-10 samples. All reagents were of analytical grade. MilliQ water was used throughout.

Statistical analyses were conducted using statistical package for social sciences (SPSS) version 16.0. Mean,

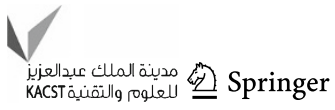


standard deviation (SD) values were used to describe trace metal concentrations for each option. The Mann-Whitney $U$ test was used to analyze the differences in trace metal concentrations between PSF ponds and PSFs.

\section{Results and discussion}

A summary of the analytical testing results is provided in Table 2. Most of the exceedences of the Bangladesh drinking water quality standards were related to high iron and manganese levels. Figures 3, 4, 5, 6, 7 shows the mean concentrations and the lines on the bars denote standard deviation for the parameters considered. Similarly, Figs. 3, 4, 5, 6, 7 compares the values proposed in guidelines of quality criteria for drinking water established by the World Health Organization (WHO 2008) and Bangladesh drinking water quality standard (GOB 1997).

$\mathrm{pH}$ and conductivity

Figure $3 \mathrm{a}$ shows the $\mathrm{pH}$ levels in drinking water. It was observed that storage tank had an effect on $\mathrm{pH}$ of harvested rainwater. The mean $\mathrm{pH}$ for CRWHSs was higher than that for the other drinking water options. The highest $\mathrm{pH}$ of 10.5 was recorded in the CRWHSs. We considered $\mathrm{pH}$ levels $>8.5$ for the calculation of the percentage of samples above guideline value. About $79 \%$ (11/14) of the CRWHS samples had a pH above 8.5. For RWHSs, the highest $\mathrm{pH}$ for the plastic and ferrocement tank was 8.5 and 9.9, respectively. The $\mathrm{pH}$ value is an important operational water quality parameter. The $\mathrm{pH}$ of rainwater usually ranges from 4.5 to 6.5 but increases slightly after falling on roof and during storage into tank. The values may vary due to mixing of other chemical components from the air or roof catchment or from storage tank. The possible reason of high $\mathrm{pH}$ in CRWHSs and ferrocement tanks of RWHSs was leaching of calcium oxide from cement used for the construction of rainwater storage tank. The finding of the present study is consistent with that of other studies (Handia 2005; Karim 2010b). Chlorine is the most commonly used disinfectant in the developing countries. Optimal $\mathrm{pH}$ level in drinking water is important for disinfection with chlorine. Chlorine dosing is less effective if $\mathrm{pH}$ levels are over 8.5 (Macomber 2001). In addition, the $\mathrm{pH}$ above 9.5 can cause a bitter taste if used for drinking purposes.

The average conductivity value for ponds and PSFs were found to be more than $1,000 \mu \mathrm{S} / \mathrm{cm}$ (Fig. 3b). Since the conductivity is a measure to the capacity of water to conduct electrical current, it is directly related to the concentration of salts dissolved in water and, therefore, to the total dissolved solids (TDS). Previous study (Harun and Kabir 2013) from southwest coastal areas of
Bangladesh have shown that pond and PSF water contains high TDS.

Calcium and magnesium

The mean $\mathrm{Ca}$ and $\mathrm{Mg}$ concentrations for all options were much lower than the Bangladesh drinking water quality standard. However, the mean concentrations for PSFs and ponds were comparatively higher than that for harvested rainwater (Fig. 4). CRWHSs showed high Ca concentrations compare to RWHSs. The possible reason of high $\mathrm{Ca}$ in CRWHSs was leaching of Ca from ferrocement tank.

The mean $\mathrm{Ca}$ and $\mathrm{Mg}$ concentrations in RWHSs showed the scarcity of these bio-essential base cations in harvested rainwater. The principal constituents of water hardness (calcium and magnesium) have been closely associated with cardiovascular diseases. This scarcity of $\mathrm{Ca}$ and $\mathrm{Mg}$ can cause several diseases to the people who use this water for drinking and cooking purposes. The mean concentrations of Mg for RWHSs and CRWHSs were extremely low. Epidemiologic study in Taiwan (Yang et al. 2006) has shown a protective effect of $\mathrm{Mg}$ from drinking water on the risk of death from cardiovascular diseases. Among the general mass, the major proportion of $\mathrm{Mg}$ intake is through food, and a smaller proportion is taken through drinking water. However, for individuals with borderline Mg deficiency, waterborne $\mathrm{Mg}$ can make an important contribution to their total intake. The recommended dietary amount for $\mathrm{Mg}$ is $6 \mathrm{mg} / \mathrm{kg} /$ day (Durlach 1989). Assuming a mean water ingestion of 21 per person per day, the estimated daily intakes of Mg from RWHSs and CRWHSs among population living in the southwest coastal Bangladesh is 0.98 and $0.88 \mathrm{mg}$, respectively, which constitute little contribution to the recommended intake levels. In addition, the loss of magnesium from food is higher when the food is cooked in magnesium-poor water (Haring and Delft 1981).

Iron

The mean concentration of $\mathrm{Fe}$ for pond water was much higher than that for the other drinking water options (Fig. 5a). The highest Fe concentration $(4,800 \mu \mathrm{g} / \mathrm{l})$ was found in pond water, it was about 5 times higher than the Bangladesh drinking water quality standard. About $41 \%$ (16/39) of the pond water had $\mathrm{Fe}$ concentrations above the Bangladesh drinking water quality standard. Shallow aquifer in the southwest coastal areas of Bangladesh contains elevated iron concentrations. The iron released from organic matter and the deduction of iron in the soil in the presence of organic matter is responsible for the dissolution of iron in water (Jorge et al. 1994). Humic substances are capable of reducing $\mathrm{Fe}^{3+}$ to $\mathrm{Fe}^{2+}$, forming stable complexes with $\mathrm{Fe}^{2+}$ and inhabiting the oxidation of $\mathrm{Fe}^{2+}$ in contact 
Table 2 Minimum, maximum and mean values of $\mathrm{pH}$, conductivity, arsenic and metals concentrations present in the drinking water sources, and comparison against the levels allowed by WHO (2008) and Government of Bangladesh (BD) (GOB 1997)

\begin{tabular}{|c|c|c|c|c|c|c|c|c|}
\hline Parameters & $\begin{array}{l}\text { Sampling } \\
\text { sources }\end{array}$ & $\begin{array}{l}\text { Mean } \\
\text { (SD) }\end{array}$ & Min & $\operatorname{Max}$ & $\begin{array}{l}\% \text { above WHO } \\
\text { guideline value }\end{array}$ & $\begin{array}{l}\% \text { above } \mathrm{BD} \\
\text { guideline value }\end{array}$ & $\begin{array}{l}\text { WHO guideline } \\
\text { value }\end{array}$ & $\begin{array}{l}\text { BD guideline } \\
\text { value }\end{array}$ \\
\hline \multirow[t]{4}{*}{$\mathrm{pH}$} & RWHSs & $7.9(1.1)$ & 5.7 & 9.9 & 22 & - & \multirow[t]{4}{*}{$6.5-8.5$} & \multirow[t]{4}{*}{ N/A } \\
\hline & CRWHSs & $8.9(0.8)$ & 7.6 & 10.5 & 79 & - & & \\
\hline & PSFs & $7.6(0.5)$ & 6.8 & 8.5 & 0 & - & & \\
\hline & Ponds & $7.8(0.4)$ & 6.9 & 8.8 & 5 & - & & \\
\hline \multirow[t]{4}{*}{ Conductivity $(\mu \mathrm{S} / \mathrm{cm})$} & RWHSs & $140(120)$ & 24 & 470 & - & - & \multirow[t]{4}{*}{ N/A } & \multirow[t]{4}{*}{ N/A } \\
\hline & CRWHSs & $170(70)$ & 94 & 340 & - & - & & \\
\hline & PSFs & $1,300(840)$ & 340 & 3,400 & - & - & & \\
\hline & Ponds & $1,200(820)$ & 350 & 3,900 & - & - & & \\
\hline \multirow[t]{4}{*}{$\mathrm{Ca}(\mathrm{mg} / \mathrm{l})$} & RWHSs & $6.2(5.5)$ & 0.4 & 19 & - & 0 & \multirow[t]{4}{*}{ N/A } & \multirow[t]{4}{*}{75} \\
\hline & CRWHSs & $13(3.1)$ & 9.4 & 19 & - & 0 & & \\
\hline & PSFs & $29(5.5)$ & 15 & 38 & - & 0 & & \\
\hline & Ponds & $17(5.1)$ & 11 & 27 & - & 0 & & \\
\hline \multirow[t]{4}{*}{ Mg (mg/l) } & RWHSs & $0.49(0.5)$ & 0.003 & 2.5 & - & 0 & \multirow[t]{4}{*}{ N/A } & \multirow[t]{4}{*}{$30-35$} \\
\hline & CRWHSs & $0.44(0.5)$ & 0.05 & 1.9 & - & 0 & & \\
\hline & PSFs & $2.7(0.5)$ & 1.8 & 3.2 & - & 0 & & \\
\hline & Ponds & $2.5(1.0)$ & 1.9 & 4.1 & - & 0 & & \\
\hline \multirow[t]{4}{*}{$\mathrm{Fe}(\mu \mathrm{g} / \mathrm{l})$} & RWHSs & $29(43)$ & 0.3 & 190 & - & 0 & \multirow[t]{4}{*}{ N/A } & \multirow[t]{4}{*}{1,000} \\
\hline & CRWHSs & $66(59)$ & 22 & 210 & - & 0 & & \\
\hline & PSFs & $240(260)$ & 2.1 & 800 & - & 0 & & \\
\hline & Ponds & $3,200(1,100)$ & 44 & 4,800 & - & 41 & & \\
\hline \multirow[t]{4}{*}{$\mathrm{Mn}(\mu \mathrm{g} / \mathrm{l})$} & RWHSs & $8.7(18)$ & 3.4 & 66 & 0 & 0 & \multirow[t]{4}{*}{400} & \multirow[t]{4}{*}{100} \\
\hline & CRWHSs & $3.2(3.9)$ & 0.5 & 15 & 0 & 0 & & \\
\hline & PSFs & $160(220)$ & 1.0 & 700 & 12 & 52 & & \\
\hline & Ponds & $180(180)$ & 1.0 & 850 & 10 & 45 & & \\
\hline \multirow[t]{4}{*}{$\mathrm{Cu}(\mu \mathrm{g} / \mathrm{l})$} & RWHSs & $3.7(8.5)$ & 0.3 & 28 & 0 & 0 & \multirow[t]{4}{*}{2,000} & \multirow[t]{4}{*}{1,000} \\
\hline & CRWHSs & $5.6(5.3)$ & 0.2 & 21 & 0 & 0 & & \\
\hline & PSFs & $24(44)$ & 0.3 & 190 & 0 & 0 & & \\
\hline & Ponds & $12(13)$ & 0.5 & 54 & 0 & 0 & & \\
\hline \multirow[t]{4}{*}{$\mathrm{Zn}(\mu \mathrm{g} / 1)$} & RWHSs & $310(440)$ & 9.5 & 1,700 & 0 & 0 & N/A & 5,000 \\
\hline & CRWHSs & $86(95)$ & 9.6 & 350 & 0 & 0 & & \\
\hline & PSFs & 37 (87) & 1.4 & 360 & 0 & 0 & & \\
\hline & Ponds & $6.2(7.8)$ & 1.3 & 40 & 0 & 0 & & \\
\hline $\mathrm{Pb}(\mu \mathrm{g} / 1)$ & RWHSs & 3.7 (15) & 0.8 & 69 & 4 & 4 & 10 & 50 \\
\hline & CRWHSs & $0.6(1.3)$ & 0.08 & 4.8 & 0 & 0 & & \\
\hline & PSFs & ND & ND & ND & 0 & 0 & & \\
\hline & Ponds & $0.1(0.5)$ & 0.008 & 2.9 & 0 & 0 & & \\
\hline $\mathrm{Cr}(\mu \mathrm{g} / \mathrm{l})$ & RWHSs & $1.2(2.9)$ & 0.02 & 13 & 0 & 0 & 50 & 50 \\
\hline & CRWHSs & $0.05(0.1)$ & 0.03 & 0.5 & 0 & 0 & & \\
\hline & PSFs & ND & ND & ND & 0 & 0 & & \\
\hline & Ponds & $1.6(1.2)$ & 1.3 & 3.8 & 0 & 0 & & \\
\hline $\mathrm{Cd}(\mu \mathrm{g} / \mathrm{l})$ & RWHSs & $0.2(0.2)$ & 0.03 & 0.6 & 0 & 0 & 3 & 5 \\
\hline & CRWHSs & ND & ND & ND & 0 & 0 & & \\
\hline & PSFs & $0.3(0.2)$ & 0.05 & 0.8 & 0 & 0 & & \\
\hline & Ponds & $0.1(0.2)$ & 0.003 & 1 & 0 & 0 & & \\
\hline
\end{tabular}


Table 2 continued

\begin{tabular}{|c|c|c|c|c|c|c|c|c|}
\hline Parameters & $\begin{array}{l}\text { Sampling } \\
\text { sources }\end{array}$ & $\begin{array}{l}\text { Mean } \\
\text { (SD) }\end{array}$ & Min & Max & $\begin{array}{l}\% \text { above WHO } \\
\text { guideline value }\end{array}$ & $\begin{array}{l}\% \text { above } \mathrm{BD} \\
\text { guideline value }\end{array}$ & $\begin{array}{l}\text { WHO guideline } \\
\text { value }\end{array}$ & $\begin{array}{l}\text { BD guideline } \\
\text { value }\end{array}$ \\
\hline \multirow[t]{4}{*}{$\mathrm{Ni}(\mu \mathrm{g} / \mathrm{l})$} & RWHSs & $0.3(0.3)$ & 0.1 & 1.2 & 0 & 0 & 70 & 100 \\
\hline & CRWHSs & $0.2(0.5)$ & 0.1 & 0.2 & 0 & 0 & & \\
\hline & PSFs & $0.04(0.1)$ & 0.1 & 0.4 & 0 & 0 & & \\
\hline & Ponds & $0.9(3.9)$ & 0.1 & 18 & 0 & 0 & & \\
\hline \multirow[t]{4}{*}{ As $(\mu \mathrm{g} / \mathrm{l})$} & RWHSs & $1.1(1.6)$ & 0.2 & 6.8 & 0 & 0 & 10 & 50 \\
\hline & CRWHSs & $0.6(0.8)$ & 0.2 & 3.1 & 0 & 0 & & \\
\hline & PSFs & $3.4(2.8)$ & 0.6 & 9.4 & 0 & 0 & & \\
\hline & Ponds & $3.8(3.4)$ & 0.5 & 18 & 3 & 0 & & \\
\hline
\end{tabular}

ND and N/A indicates not detected and no published WHO and BD guideline, respectively

Fig. 3 Mean $\mathrm{pH}$ and conductivity in drinking water options with standard deviation. WHO GV WHO guideline value, $B D G V$ Bangladesh guideline value

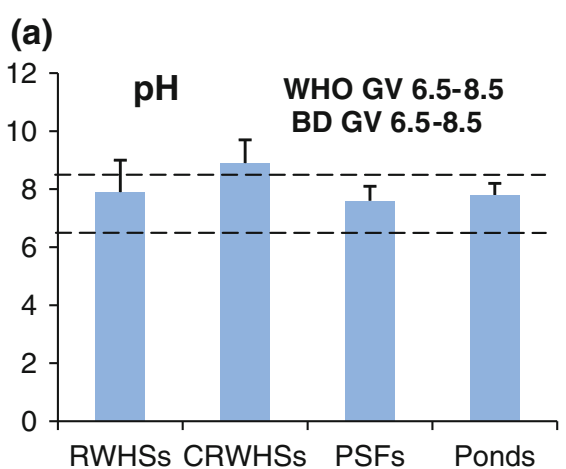

\section{(a)}

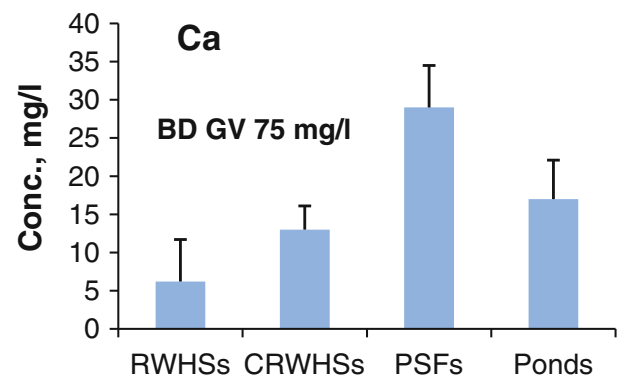

Fig. 5 Mean $\mathrm{Fe}$ and $\mathrm{Mn}$ in drinking water options with standard deviation
Fig. 4 Mean $\mathrm{Ca}$ and $\mathrm{Mg}$ in drinking water options with standard deviation

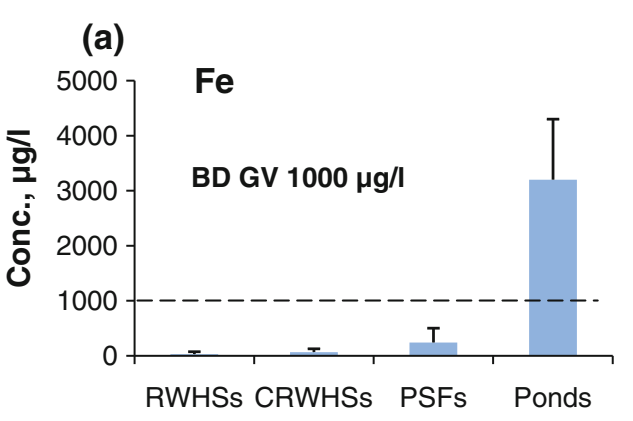

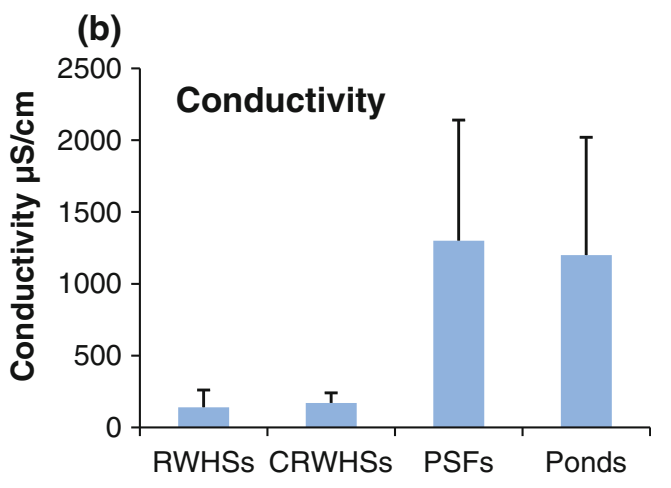

(b)
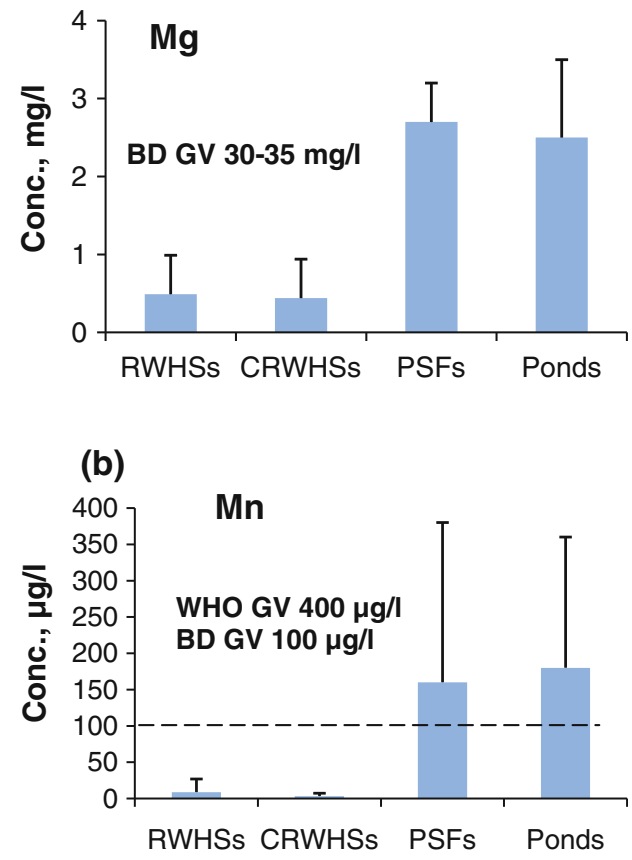

with air, thus enhancing the water concentration of iron (Livens 1991). The highest Fe concentrations for RWHSs and CRWHSs were about 5 times lower than the Bangladesh drinking water quality standard. The high $\mathrm{Fe}$ concentrations in pond water assigned for human consumption can create a risk for human health since excess accumulation of $\mathrm{Fe}$ is correlated with the oxygen-free radical formation, which may be carcinogenic (Stevens 1990). 
Fig. 6 Mean $\mathrm{Cu}$ and $\mathrm{Zn}$ in drinking water options with standard deviation

Fig. 7 Mean $\mathrm{Pb}, \mathrm{Cr}, \mathrm{Cd}, \mathrm{Ni}$ and AS in drinking water options with standard deviation
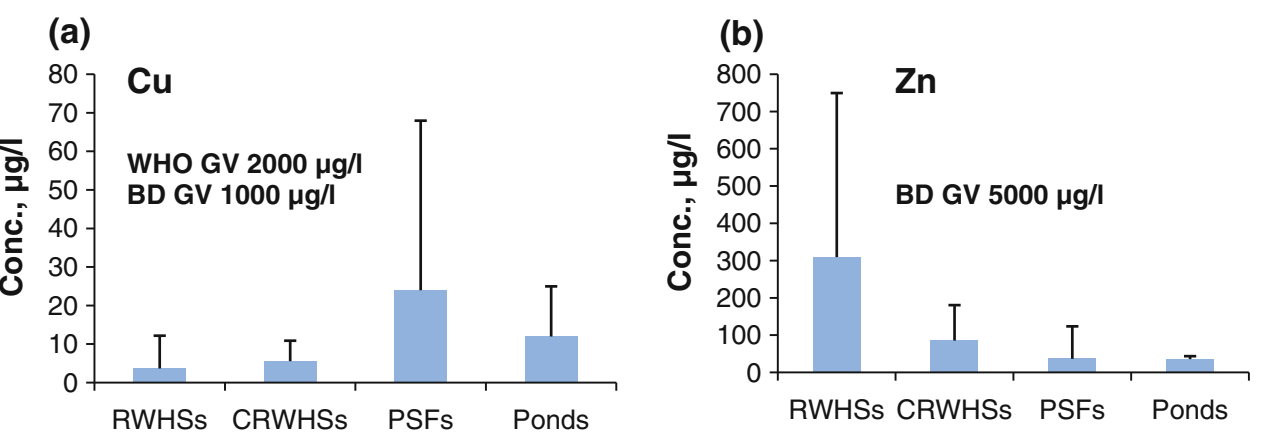

(a)

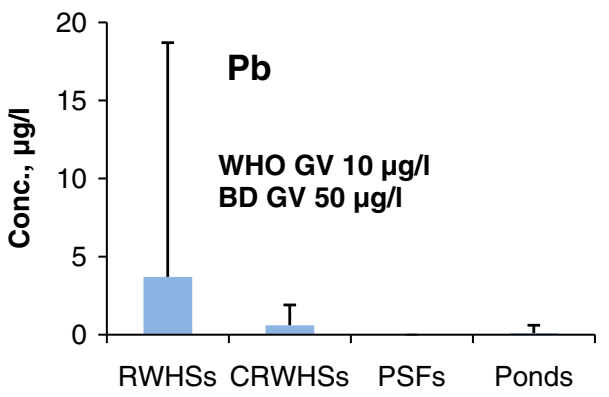

(b)

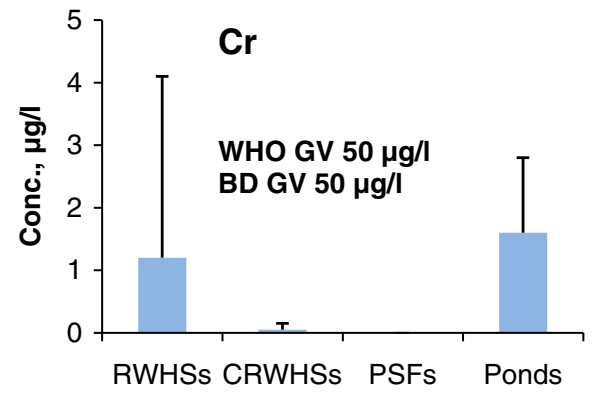

(c)
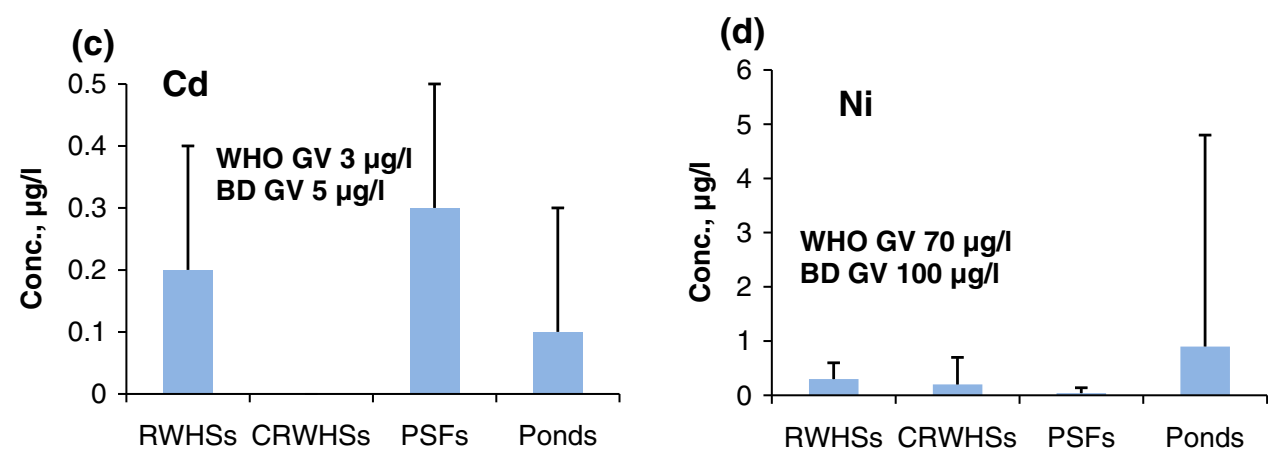

\section{(e)}

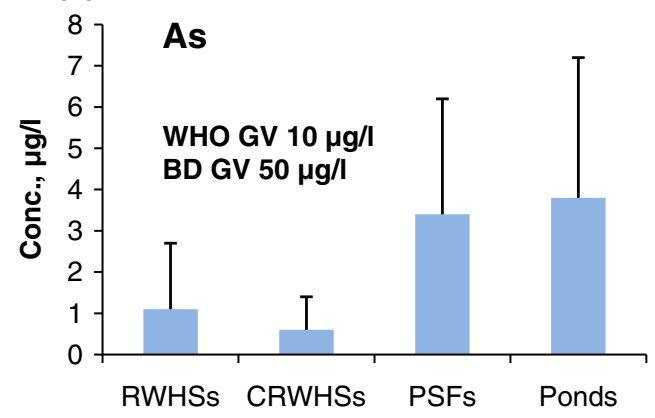

Manganese

The mean Mn concentrations for PSFs and ponds were higher than that prescribed by the Bangladesh drinking water quality standard (Fig. 5b). The highest Mn concentration $850 \mu \mathrm{g} / \mathrm{l}$ was found in pond water sample. Manganese occurs naturally in soils that may erode into surface water (WHO 2011). The primary source of Mn in pond and PSF water may have been dissolution of naturally occurring manganese present in the soil. In the present study, $52 \%(9 / 17)$ of the PSF and $45 \%$ (18/39) of the pond water samples showed Mn concentrations higher than the Bangladesh drinking water quality standard. The accumulation of $\mathrm{Mn}$ in blood may cause hepatic encephalopathy 
(Layrargues et al. 1998). High manganese concentrations in drinking water have also been shown to affect intellectual functions in 10-year-old children in Araihazar, Bangladesh (Wasserman et al. 2006).

\section{Copper}

Figure 6a shows the mean $\mathrm{Cu}$ concentrations. The highest $\mathrm{Cu}$ concentration $(190 \mu \mathrm{g} / \mathrm{l})$ was found in PSF water; however, the concentration was about 11 and 5 times lower than the WHO and Bangladesh drinking water quality standard. Even though $\mathrm{Cu}$ concentrations in the drinking water options assessed in our study were lower than the values recommended by $\mathrm{WHO}$ and Bangladesh drinking water quality standard, the mean $\mathrm{Cu}$ concentrations for RWHSs and CRWHSs were extremely low. This $\mathrm{Cu}$ scarcity in drinking water could cause deficiency, since $\mathrm{Cu}$ is considered as bio-essential metal.

\section{Zinc}

The mean $\mathrm{Zn}$ concentrations for all options were very low compared to the Bangladesh drinking water quality standard (Fig. 6b). However, the concentrations in RWHSs and CRWHSs were higher than PFSs and ponds. RWHSs showed the highest $\mathrm{Zn}$ concentration of $1,700 \mu \mathrm{g} / \mathrm{l}$. The possible source of $\mathrm{Zn}$ in harvested rain water was roof catchments. High zinc concentrations were measured from zinc-covered roof due to erosion of zinc (Gromaire et al. 2002).

Lead

The mean $\mathrm{Pb}$ concentrations for all drinking water options were lower than the WHO guideline value (Fig. 7a). However, one RWHS sample showed $\mathrm{Pb}$ concentration about 7 times higher than the WHO guideline value. The source of $\mathrm{Pb}$ in harvested rainwater may have been roof catchment. High $\mathrm{Pb}$ concentrations were also observed in runoff from galvanized iron roof (Simmons et al. 2001). Lead is a "possible human carcinogen" because of inconclusive evidence of human and sufficient evidence of animal carcinogenicity. In addition, the $10 \mu \mathrm{g} / \mathrm{l}$ WHO drinking water guideline for $\mathrm{Pb}$ was calculated using the lowest measurable retention of $\mathrm{Pb}$ in the blood and tissues of human infants (WHO 1996).

Chromium, cadmium and nickel

The mean concentrations of $\mathrm{Cr}, \mathrm{Cd}$ and $\mathrm{Ni}$ for all options were lower than the guideline values (Fig. 7). The highest concentrations of $\mathrm{Cd}$ and $\mathrm{Ni}$ were found in pond water, while RWHSs showed the highest $\mathrm{Cd}$ concentration.
Table 3 Removal efficiencies of Fe and Mn by PSFs

\begin{tabular}{llll}
\hline $\begin{array}{l}\text { Trace metal } \\
(\mu \mathrm{g} / \mathrm{l})\end{array}$ & $\begin{array}{l}\text { PSF ponds } \\
(\text { mean })\end{array}$ & $\begin{array}{l}\text { PSFs } \\
(\text { mean })\end{array}$ & $\begin{array}{l}\text { Average \% removal } \\
\text { by PSFs }\end{array}$ \\
\hline $\mathrm{Fe}$ & 1,300 & 240 & 74 \\
$\mathrm{Mn}$ & 220 & 160 & 51 \\
\hline
\end{tabular}

\section{Arsenic}

All the drinking water options showed mean As concentrations below the WHO and Bangladesh drinking water quality standard (Fig. 7e). However, one pond water sample showed As concentration above the $10 \mu \mathrm{g} / \mathrm{l}$ WHO guideline value. Previous studies (Yokota et al. 2001; Howard et al. 2006) from arsenic affected areas of Bangladesh have shown that pond and PSF water may contain arsenic higher than WHO guideline value. The arsenic in the pond water was probably due to surface drainage from an arsenic polluted tube well.

Removal of iron and manganese by PSFs

Table 3 shows the mean Fe and Mn concentrations for PSF water and the relevant PSF pond water. The PSFs reduced $\mathrm{Fe}$ concentrations significantly. However, the removal of Mn by PSFs was not found statistically significant. We also examined the removal efficiency of $\mathrm{Fe}$ and Mn by PSFs. The removal efficiency of Fe and Mn by PSFs is shown in Table 3. In the present study, $\mathrm{Fe}$ and $\mathrm{Mn}$ removed by the PSFs was about 74 and $51 \%$, respectively. Si-min et al. (2010) found higher Fe and Mn removed by bio-sand filter compare to the present study. Thus consumption of PSF water instead of pond water may reduce the health risk from Fe and Mn exposure. The removal of other metals by PSFs was negligible.

\section{Conclusions}

The mean concentrations of the metals under consideration complied with international guidelines of quality criteria for drinking water. However, the mean Fe and Mn concentrations for pond water and the mean $\mathrm{Mn}$ concentration for PSF water were higher than the Bangladesh guideline value. The CRWHS samples showed an average $\mathrm{pH}$ of 8.9. Thus, harvested rainwater can show $\mathrm{pH}$ levels above the limit of 8.5 due to the influence of the ferro-cement tanks. The scarcity of $\mathrm{Ca}$ and $\mathrm{Mg}$ in harvested rainwater is of importance to the health of populations in the study area. We recommend $\mathrm{Ca}$ and $\mathrm{Mg}$ supplementation as a possible way of reducing the risk of heart and other diseases for populations entirely dependent on harvested rainwater. 
Methods of supplementary $\mathrm{Ca}$ and $\mathrm{Mg}$ can include fortification of foods, and public education to change dietary habits. This study reveals high concentrations of $\mathrm{Fe}$ and $\mathrm{Mn}$ in pond water. Conversely, $\mathrm{Fe}$ and $\mathrm{Mn}$ removal by PSFs was found to be 74 and $51 \%$, respectively. Thus consumption of PSFs water instead of pond water will reduce associated health risk. In addition, ponds should be well protected to ensure sufficient protection from surface run off and for efficient filter operation.

Acknowledgments The authors would like to thank the students of Environmental Science Discipline (Sabuj, Sumon, Mahmudul, Farhan, Shamim, Uzzal, Subindu and Arif), Khulna University, Bangladesh for their cooperation during sample collection and $\mathrm{Mr}$. Kenshin Terachi for his help during the laboratory analysis. Financial support from Japanese Government (Monbukagakusho) (MEXT) during this study is gratefully acknowledged.

Open Access This article is distributed under the terms of the Creative Commons Attribution License which permits any use, distribution, and reproduction in any medium, provided the original author(s) and the source are credited.

\section{References}

APHA (1998) Standard methods for the examination of water and wastewater, 20th edn. American Public Health Association/ American Water Works Association/Water Environment Federation, Washington, DC

Durlach J (1989) Recommended dietary amounts of magnesium: Mg RDA. Magnes Res 2:195-203

GOB (1997) Environmental conservation rules-1997. In: Bangladesh Gazette, Ministry of Environment and Forests, Government of People's Republic of Bangladesh, 27 Aug 1997

GOB (2000) Groundwater studies for arsenic contamination in Bangladesh. In: Government of the People's Republic of Bangladesh, Department for International Development (UK), British Geological Survey, Draft Final Report Summary, March 2000

Gromaire MC, Chebbo G, Constant A (2002) Impact of zinc roofing on urban runoff pollutant load, the case of Paris. Water Sci Technol 45:113-121

Handia L (2005) Comparative study of rainwater quality in urban Zambia. J Water Suppl: Res Technol AQUA 54:55-64

Haring BS, Delft VW (1981) Changes in the mineral composition of food as a result of cooking in hard and soft waters. Arch Environ Health 36:33-35

Harun MAYA, Kabir GMM (2013) Evaluating pond sand filter as sustainable drinking water supplier in the Southwest coastal region of Bangladesh. Appl Water Sci 3:161-166

Howard G, Ahmed MF, Shamsuddin AF, Mahmud SG, Deere D (2006) Risk assessment of arsenic mitigation options in Bangladesh. J Health Popul Nutr 24:346-355

Jorge ET, Jose MS, Hernan SC, Romer AR (1994) Metal content of drinking water supplied to the city of Maracaibo, Venezuela. Sci Total Environ 144:59-71
Kamruzzaman AKM, Ahmed F (2006) Study of Performance of existing pond sand filters in different parts of Bangladesh. In: Sustainable development of water resources, water supply and environmental sanitation, 32nd WEDC conference, Colombo, Sri Lanka, pp 377-380

Karim MR (2010a) Microbial contamination and associated health burden of rainwater harvesting in Bangladesh. Water Sci Technol 6:2129-2135

Karim MR (2010b) Quality and suitability of harvested rainwater for drinking in Bangladesh. Water Sci Technol: Water Suppl 10:359-366

Layrargues GP, Rose C, Spahr L, Zayed J, Normandin L, Butterworth RF (1998) Role of manganese in the pathogenesis of the portalsystematic encephalopathy. Metab Brain Dis 13:311-318

Livens FR (1991) Chemical reactions of metals with humic material. Environ Pollut 70:183-208

Macomber PSH (2001) Guidelines on rainwater catchment systems for Hawaii. In: College of tropical Agriculture and Human Resources, University of Hawaii, Manoa, Publication no RM-12

Magyar MI, Mitchell VG, Ladson AR, Diaper C (2008) Lead and other heavy metals common contaminants of rainwater tanks in Melbourne. In: Proceedings of Water Down Under 2008, Adelaide, Australia, pp 409-417

Si-min L, Zhoa B, Shi Z, Zhang W (2010) Removal of iron and manganese from micro-polluted surface water using bio-sand filtration system. In: International conference on mechanic automation and control engineering (MACE), IEEE xplore, Wuhan, China, pp 1980-1983

Simmons G, Hope V, Lewis G, Whitmore J, Gao W (2001) Contamination of roof-collected rain water in Auckland, New Zealand. Water Res 35:1518-1524

Stevens RG (1990) Iron and the risk of cancer. Med Oncol Tumor Pharmacother 7:177-181

Uba BN, Aghogho O (2000) Rainwater quality from different roof catchment in the Port Harcourt District, Rivers State, Nigeria. J Water Suppl: Res Technol AQUA 49:281-288

Ward S, Memon FA, Butter D (2010) Harvested rainwater quality: the importance of appropriate design. Water Sci Technol 61:1707-1714

Wasserman G, Liu X, Parvez F, Ahsan H, Levy D, Factor-Litvak P, Kline J, An Geen A, Slavkovich V, Lolacono N, Cheng Z, Zheng Y, Graziano J (2006) Water manganese exposure and children's intellectual functions in Araihazar, Bangladesh. Environ Health Perspect 114:124-129

WHO (1996) Guidelines for drinking-water quality-health criteria and other supporting information. WHO, Geneva

WHO (2008) Guidelines for drinking water quality. Recommendations, 3rd edn. WHO, Geneva

WHO (2011) Manganese in drinking-water, background document for development of who guidelines for drinking-water quality. WHO, Geneva

Yang CY, Chang CC, Tsai SS, Chiu HF (2006) Calcium and magnesium in drinking water and risk of death from acute myocardial infarction in Taiwan. Environ Res 101:407-411

Yokota H, Tanabe K, Sezaki M, Akiyoshi Y, Miyata T, Kawahara K, Tsushima S, Hironaka H, Takafuji H, Rahman M, Ahmed SkA, Sayed MHSU, Faruquee MH (2001) Arsenic contamination of ground and pond water and water purification system using pond water in Bangladesh. Eng Geol 60:323-331

Zatta P, Lucchini R, van Rensburg S, Taylor A (2003) The role of metals in neurodegenerative processes: aluminum, manganese, and zinc. Brain Res Bull 62:15-28 